\title{
Lower Esophageal Sphincter
}

National Cancer Institute

\section{Source}

National Cancer Institute. Lower Esophageal Sphincter. NCI Thesaurus. Code C33009.

A group of muscles between the esophagus and stomach that actively prevents food from rising up out of the stomach. 